\title{
Dual Wavelength Spectrophotometric Method for Simultaneous Estimation of Atorvastatin Calcium and Felodipine from Tablet Dosage Form
}

\author{
Namdeo R. Jadhav, Ramesh S. Kambar, and Sameer J. Nadaf \\ Department of Pharmaceutics, Bharati Vidyapeeth College of Pharmacy, Kolhapur, Maharashtra 416013, India \\ Correspondence should be addressed to Namdeo R. Jadhav; nrjadhav18@rediffmail.com
}

Received 24 May 2014; Revised 17 July 2014; Accepted 29 July 2014; Published 21 August 2014

Academic Editor: Yun Wei

Copyright (C) 2014 Namdeo R. Jadhav et al. This is an open access article distributed under the Creative Commons Attribution License, which permits unrestricted use, distribution, and reproduction in any medium, provided the original work is properly cited.

\begin{abstract}
Atorvastatin calcium (ATR) and felodipine (FEL) are beneficial in combination for elderly people in management of hypertension and atherosclerosis. Aim of present study is to develop simple, accurate, and precise method for simultaneous quantitative estimation of ATR and FEL from combined tablet dosage form. Method involves simultaneous equation, using acetonitrile-double distilled water $(70: 30)$ - common solvent showing absorption maxima at 245 and $268 \mathrm{~nm}$. Calibration curves determination for both drugs has been carried out in $0.1 \mathrm{~N} \mathrm{HCl}$, phosphate buffer $\mathrm{pH} 6.8$, and acetonitrile $(\mathrm{ACN})$ - water $(70: 30 \mathrm{~V} / \mathrm{V})$. Linearity range was observed in the concentration range of 2 to $12 \mu \mathrm{g} / \mathrm{mL}$ for FEL and 20 to $100 \mu \mathrm{g} / \mathrm{mL}$ for ATR. Percent concentration estimated for ATR and FEL was $100.12 \pm 1.03$ and $99.98 \pm 0.98$, respectively. The method was found to be simple, economical, accurate and precise and can be used for quantitative estimation of ATR and FEL.
\end{abstract}

\section{Introduction}

Atorvastatin (ATR) is chemically described as $\left[\mathrm{R}-\left(\mathrm{R}^{*}, \mathrm{R}^{*}\right)\right]$ 2-(4-fluorophenyl)-dihydroxy-5-(1-methylethyl)-3-phenyl4-[(phenylamino) carbonyl]-1H-pyrrole-1-heptanoic acid (Figure 1). It is a member of the drug class known as statins, used for lowering blood cholesterol [1]. It also stabilizes plaque and prevents strokes through anti-inflammation and other mechanisms. It inhibits HMG-CoA (3-hydroxy-3methylglutaryl-coenzyme A) reductase, an enzyme found in liver tissue that plays a key role in production of cholesterol in the body. Inhibition of this enzyme stops the reduction of HMG-CoA to mevalonate, which is the rate-limiting step in hepatic cholesterol biosynthesis. Inhibition of the enzyme decreases cholesterol synthesis and ultimately increases expression of low-density lipoprotein receptors (LDL receptors) on hepatocytes $[2,3]$.

Felodipine (FEL) is a 1, 4 dihydropyridine derivative, that is, chemically described as ethyl methyl-1,4-dihydro-2,6dimethyl-4-(2,3 dichlorophenyl)-3,5-pyridinedicarboxylate. It is a dihydropyridine calcium channel blocker used mainly for the management of hypertension and angina pectoris like the other calcium channel blockers [4].

Literature survey reveals that spectrophotometric and chromatographic methods, and a stability-indicating LC method, have been reported for determination of ATR in pharmaceutical preparations in combination with other drugs [5-13]. Several chromatographic and spectrophotometric methods have been reported for felodipine assay [1418]. However, most of the analytical methods developed for the quantization of ATR and FEL involve analysis of single component or combination with other drugs. No effective method has been reported for quantitative estimation of ATR and FEL from combined dosage form.

\section{Material and Methods}

Atorvastatin calcium and felodipine were kindly gifted by Cipla Ltd., Goa, India. Acetonitrile (Loba Chemie Pvt. Ltd., Mumbai, India) and other chemicals used are of analytical grade. Distilled water was prepared in laboratory. 
TABLE 1: Absorbance values for calibration curves of FEL and ATR at 268 and $245 \mathrm{~nm}$.

\begin{tabular}{|c|c|c|c|c|c|}
\hline \multicolumn{3}{|c|}{ FEL } & \multicolumn{3}{|c|}{ ATR } \\
\hline \multirow{2}{*}{ Concentration $(\mu \mathrm{g} / \mathrm{mL})$} & \multicolumn{2}{|c|}{ Absorbance } & \multirow{2}{*}{ Concentration $(\mu \mathrm{g} / \mathrm{mL})$} & \multicolumn{2}{|c|}{ Absorbance } \\
\hline & $268 \mathrm{~nm}$ & $245 \mathrm{~nm}$ & & $268 \mathrm{~nm}$ & $245 \mathrm{~nm}$ \\
\hline 20 & 0.17069 & 0.05085 & 2 & 0.12878 & 0.02782 \\
\hline 40 & 0.33971 & 0.10072 & 4 & 0.24756 & 0.05264 \\
\hline 60 & 0.52023 & 0.15256 & 6 & 0.37096 & 0.08296 \\
\hline 80 & 0.68275 & 0.21401 & 8 & 0.50512 & 0.11161 \\
\hline 100 & 0.84833 & 0.25425 & 10 & 0.62368 & 0.13909 \\
\hline- & - & - & 12 & 0.76792 & 0.16704 \\
\hline
\end{tabular}

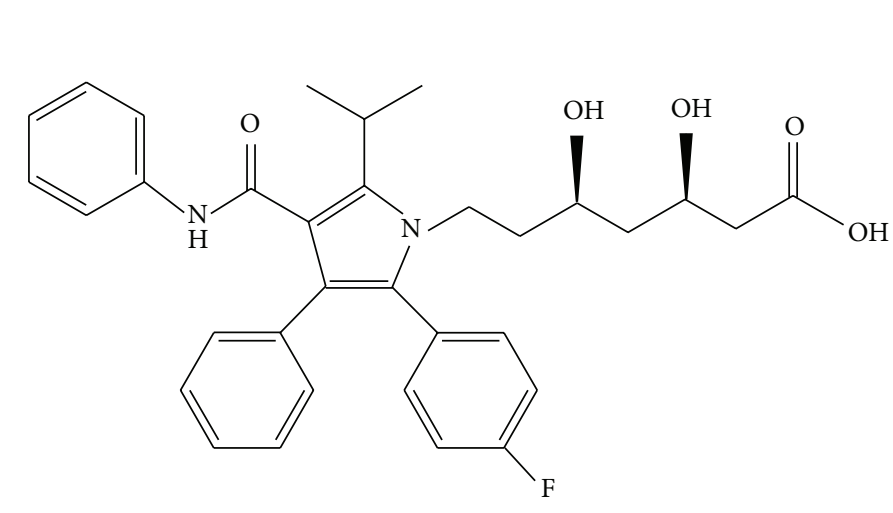

(I)<smiles>CCOC(=O)C1=C(C)NC(C)=C(C(=O)OC)C1c1cccc(Cl)c1Cl</smiles>

(II)

FIGURE 1: Structure of (I) atorvastatin, (II) felodipine.

2.1. Preparation of Bilayered Tablet. Bilayered tablets of total weight of $300 \mathrm{mg}$ each, containing $150 \mathrm{mg}$ immediate release layer of ATR (10 mg API) and $150 \mathrm{mg}$ of sustained release layer of FEL (10 mg API), were prepared by initially adding FEL granules to die of RIMEK minipress (Karnavati engineering, Gujarat, India) and compressed, above which ATR blend was poured and allowed to undergo for the final compression to prepare the bilayered tablet using $8 \mathrm{~mm}$ flat faced punches.

\subsection{Standard Stock Solution}

2.2.1. In $0.1 \mathrm{~N} \mathrm{HCl}$. Standard stock solution was prepared by dissolving $10 \mathrm{mg}$ of ATR and $10 \mathrm{mg}$ of FEL separately in $100 \mathrm{~mL}$ of volumetric flask containing $10 \mathrm{~mL}$ of $0.1 \mathrm{~N} \mathrm{HCl}$. Then, the final volume of the solution was made up to $100 \mathrm{~mL}$ with $0.1 \mathrm{~N} \mathrm{HCl}$ to get stock solution of $100 \mu \mathrm{g} / \mathrm{mL}$. Adequate quantities were sampled out from the standard stock solution in $10 \mathrm{~mL}$ volumetric flask to get concentration of $10,20,30$, 40,50 , and $60 \mu \mathrm{g} / \mathrm{mL}$ ATR and $2,4,6,8,10$, and $12 \mu \mathrm{g} / \mathrm{mL}$ FEL. Then, the absorbances of the solution was measured at $268 \mathrm{~nm}$ ( $\lambda$ max of FEL) and $245 \mathrm{~nm}$ ( $\lambda$ max of ATR) using double beam UV visible spectrophotometer against $0.1 \mathrm{~N} \mathrm{HCl}$ as blank.

2.2.2. In Phosphate Buffer $p H$ 6.8. All the above procedure was repeated using phosphate buffer $\mathrm{pH} 6.8$ instead of $0.1 \mathrm{~N}$ $\mathrm{HCl}$. Calibration curve of ATR and FEL in $0.1 \mathrm{~N} \mathrm{HCl}$ and phosphate buffer (PB) pH 6.8 are shown in Figures 2 and 3, respectively. Absorbance values are shown in Table 1.

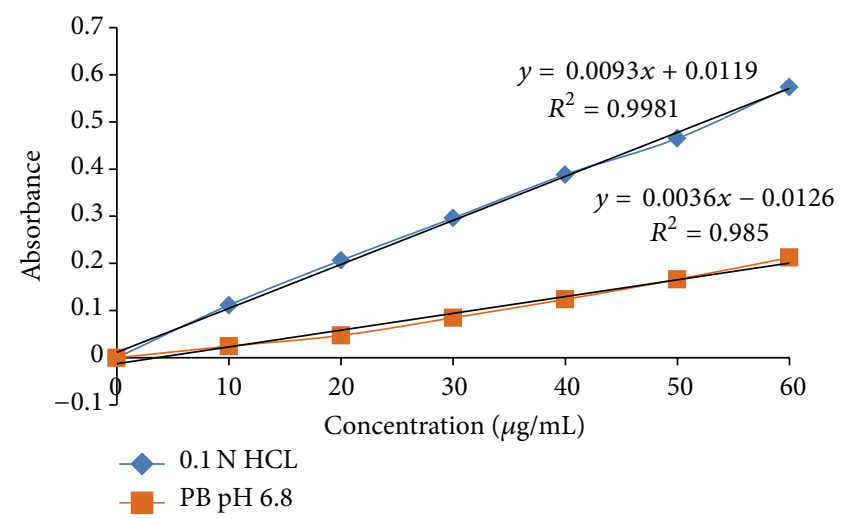

FIgURE 2: Calibration curve of ATR in $0.1 \mathrm{~N} \mathrm{HCl}$ and phosphate buffer (PB) pH 6.8 .

\subsection{UV Method Development and Optimization}

2.3.1. Selection of Common Solvent. ACN-double distilled water $(70: 30 \% \mathrm{~V} / \mathrm{V})$ - was selected as common solvent for developing spectral characteristics of drugs. The selection was made after assessing the solubility of both drugs in different solvents.

\subsubsection{Preparation of Standard Drug Solution}

(1) ATR Standard Stock Solution $(100 \mu \mathrm{g} / \mathrm{mL})$. Accurately weighed quantity of Atorvastatin calcium (10 mg) was transferred into $100 \mathrm{~mL}$ volumetric flask dissolved in $60 \mathrm{~mL}$ of 


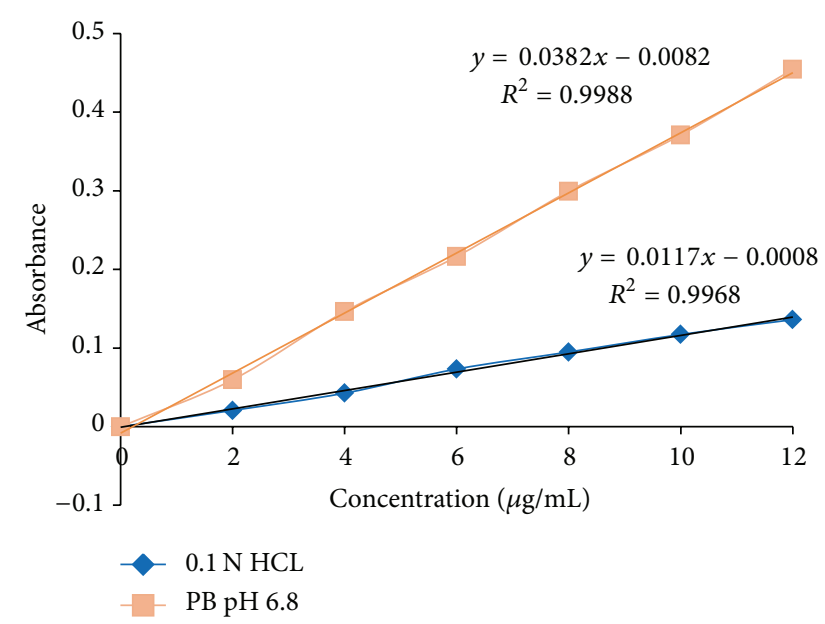

FIgure 3: Calibration curve of FEL in $0.1 \mathrm{~N} \mathrm{HCl}$ and phosphate buffer (PB) pH 6.8 .

$\operatorname{ACN}$-water $(70: 30 \% \mathrm{~V} / \mathrm{V})$ - and diluted up to mark with same solvent. This will give a stock solution having strength of $100 \mu \mathrm{g} / \mathrm{mL}$.

(2) FEL Standard Stock Solution $(100 \mu \mathrm{g} / \mathrm{mL})$. Accurately weighed quantity of felodipine $(10 \mathrm{mg}$ ) was transferred into $100 \mathrm{~mL}$ volumetric flask dissolved in $60 \mathrm{~mL}$ of ACN-water (70:30\% V/V) — and diluted up to mark with same solvent. This will give a stock solution having strength of $100 \mu \mathrm{g} / \mathrm{mL}$.

\subsubsection{Construction of Calibration Curve}

(1) Calibration Curve for ATR. Different aliquots were withdrawn from the standard stock solution and diluted with appropriate quantity of $\mathrm{ACN}$-water $(70: 30 \% \mathrm{~V} / \mathrm{V})$ - to get a series of concentration ranging from 20 to $100 \mu \mathrm{g} / \mathrm{mL}$. Absorbance was measured at different concentrations and the calibration curve was prepared by plotting absorbance versus concentration.

(2) Calibration Curve for FEL. Different aliquots were withdrawn from the standard stock solution and diluted with appropriate quantity of $\mathrm{ACN}$-water $(70: 30 \% \mathrm{~V} / \mathrm{V})$ - to get a series of concentration ranging from 2 to $12 \mu \mathrm{g} / \mathrm{mL}$. Absorbance was measured at different concentrations and the calibration curve was prepared by plotting absorbance versus concentration.

2.3.4. Selection of Wavelength. By appropriate dilutions of two standard drug solutions with ACN-double distilled water $(70: 30 \% \mathrm{~V} / \mathrm{V})$ - solutions containing $10 \mu \mathrm{g} / \mathrm{mL}$ of ATR and $10 \mu \mathrm{g} / \mathrm{mL}$ of FEL were scanned separately in the range of 200-400 nm to determine the wavelength of maximum absorption for both drugs (Figure 4).

2.3.5. Selection of Method and Wavelength. For quantitative estimation of ATR and FEL, simultaneous equation method employing $245 \mathrm{~nm}$ and $268 \mathrm{~nm}$ as analytical wavelength was used. The two wavelengths were chosen from the overlain spectra of ATR and FEL. Overlain spectra of ATR and FEL are shown in Figure 5.

2.4. Procedure for Calculating Absorptivity of Both the Drugs at Selected Wavelengths. From standard drug solutions, six works in standard solutions with concentration of $20,40,60$, 80 , and $100 \mu \mathrm{g} / \mathrm{mL}$ for ATR and $2,4,6,8,10$, and $12 \mu \mathrm{g} / \mathrm{mL}$ for FEL were prepared and scanned separately on the selected wavelengths for both the drugs. The absorptivity at selected wavelength was calculated.

2.5. Analysis of Tablet Formulation. Twenty tablets were powdered. Tablet formulation containing ATR $10 \mathrm{mg}$ and FEL $10 \mathrm{mg}$ was analyzed using this method. From the triturates of 3 tablets, an amount equivalent to $10 \mathrm{mg}$ of ATR and $10 \mathrm{mg}$ of FEL was weighed and dissolved in $10 \mathrm{~mL}$ of $\mathrm{ACN}$-water $(70: 30 \% \mathrm{~V} / \mathrm{V})$ - and sonicated for $10 \mathrm{~min}$. Then, the solution was filtered through Whatman filter paper number 41 and then final volume of the solution was made up to $100 \mathrm{~mL}$ with ACN-double distilled water $(70: 30 \% \mathrm{~V} / \mathrm{V})$ — to get a stock solution containing $100 \mu \mathrm{g} / \mathrm{mL}$ of ATR and $100 \mu \mathrm{g} / \mathrm{mL}$ FEL.

Appropriate aliquots of ATR and FEL within Beer's law limit were taken and analyzed by the proposed method using the procedure described earlier. The concentration of ATR and FEL present in the sample solution was calculated by using the simultaneous equation,

$$
\begin{aligned}
& C_{y}=\frac{A_{1} a_{x 2}-A_{2} a_{x 1}}{a_{x 2} a_{y 1}-a_{x 1} a_{y 2}}, \\
& C_{x}=\frac{A_{1} a_{y 2}-A_{2} a_{y 1}}{a_{x 2} a_{y 1}-a_{x 1} a_{y 2}},
\end{aligned}
$$

where $C_{y}$ is the concentration of ATR in gm/lit, $C_{x}$ is the concentration of FEL in gm/lit, $A_{1}$ is the absorbance of sample solution at $268 \mathrm{~nm}, A_{2}$ is the absorbance of sample solution at $245 \mathrm{~nm}, a_{x 1}$ is the absorptivity of FEL at $268 \mathrm{~nm}$, $a_{y 1}$ is the absorptivity of ATR at $268 \mathrm{~nm}, a_{x 2}$ is the absorptivity of FEL at $245 \mathrm{~nm}$, and $a_{y 2}$ is the absorptivity of ATR at $245 \mathrm{~nm}$.

\subsection{Method Validation}

2.6.1. Linearity. In quantitative analysis, the calibration curve was constructed for both ATR and FEL after analysis of consecutively increased concentrations.

2.6.2. Recovery Studies. Accuracy of analysis was determined by performing recovery studies by spiking different concentrations of pure drug in the preanalyzed tablet samples within the analytical concentration range of the proposed method at three different sets at levels of 80,100 , and $120 \%$. The added quantities of the individual drugs were estimated by above method. Intraday precision and interday precision have also been carried out. 
TABLE 2: Absorptivity values for ATR and FEL.

\begin{tabular}{lccccc}
\hline \multirow{2}{*}{ Concentration $(\mu \mathrm{g} / \mathrm{mL})$} & \multicolumn{2}{c}{ Absorptivity of FEL } & \multirow{2}{*}{ Concentration $(\mu \mathrm{g} / \mathrm{mL})$} & \multicolumn{2}{c}{ Absorptivity of ATR } \\
& $268 \mathrm{~nm}$ & $245 \mathrm{~nm}$ & $208 \mathrm{~nm}$ & 0.08533 \\
\hline 2 & 0.00603 & 0.001399 & 40 & 0.08539 & 0.0254 \\
4 & 0.00618 & 0.00148 & 60 & 0.08548 \\
6 & 0.00638 & 0.001462 & 80 & 0.08562 \\
8 & 0.00654 & 0.001495 & 100 & 0.08586 \\
10 & 0.00673 & 0.001516 & - & -0.0299 \\
12 & 0.00698 & 0.001543 & Mean & 0.0331 \\
Mean & $\mathbf{0 . 0 0 7 5 9}$ & $\mathbf{0 . 0 0 1 4 6 5}$ & $\mathbf{0 . 0 8 5 5 3}$ & $\mathbf{0 . 0 2 8 6}$ \\
S.D. & $\mathbf{0 . 4 4}$ & $\mathbf{1 . 0 3}$ & S.D. & $\mathbf{1 . 3 9}$ \\
\hline
\end{tabular}

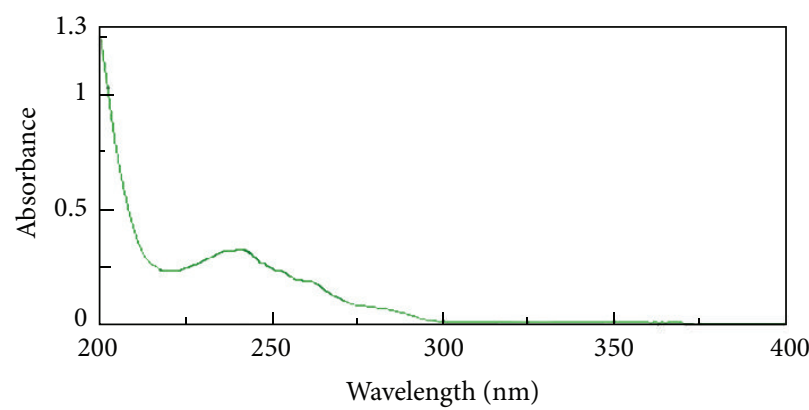

(a)

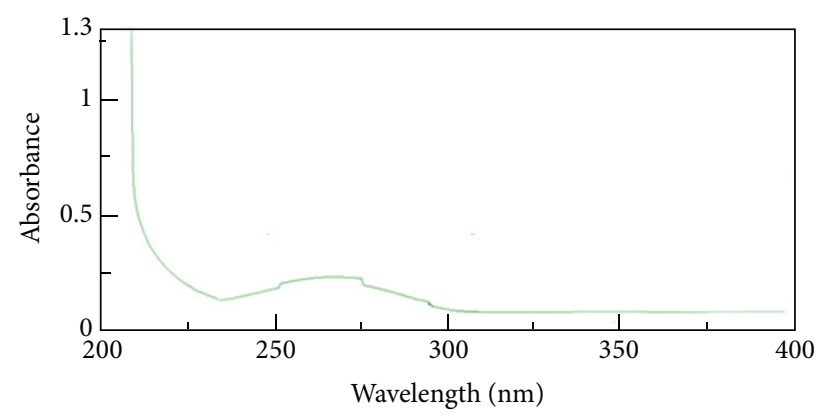

(b)

Figure 4: UV spectra of (a) ATR, (b) FEL in ACN: water (70:30\% V/V).

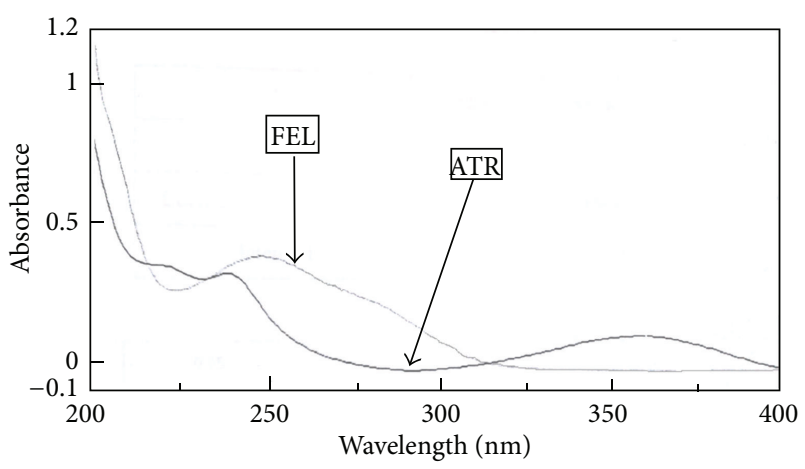

FIgURE 5: Overlain spectra of ATR and FEL.

2.6.3. Interday Precision. Analysis of drug was performed on two different days and the deviation in the results was observed. Results are shown in Table 4.

2.6.4. Intraday Precision. Analysis of drug was performed on the same day in morning and evening, and the deviation in the results was observed. Results are shown in Table 5.

2.6.5. Ruggedness. Ruggedness of the method was confirmed by the analysis of formulation that was done by the different analysts, using similar operational and environmental conditions.

\section{Result and Discussion}

Calibration curve of ATR and FEL was plotted by measuring the absorbance of prepared dilutions of the aforesaid different
TABLE 3: Results of analysis of laboratory samples.

\begin{tabular}{lc}
\hline Label claim $(\mathrm{mg} / \mathrm{tab})$ & \% concentration estimated \\
\hline ATR & $100.12 \pm 1.03$ \\
FEL & $99.98 \pm 0.98$ \\
\hline
\end{tabular}

*Indicates $\pm \mathrm{SD}(n=9)$.

concentrations at their respective wavelength of maximum absorbance (Figures 6 and 7).

3.1. Linearity. Linear regression data showed a good linear relationship over a concentration range of 2 to $12 \mu \mathrm{g} / \mathrm{mL}$ for FEL and 20 to $100 \mu \mathrm{g} / \mathrm{mL}$ for ATR, whereas, Rajesh et al. demonstrated that linearity was within the range of 2$10 \mu \mathrm{g} / \mathrm{mL}$ for each atorvastatin calcium and felodipine [19]. Six point regression data at both wavelengths (268 nm 245 $\mathrm{nm}$ ) were generated for FEL (Table 2).

\subsection{Tablet Analysis. See Table 3.}

3.3. Recovery Study. The added quantities of added drug were estimated by simultaneous equation (Table 4 ).

3.4. Interday Precision. Interday precision study was performed and method was found to be precise.

3.5. Intraday Precision. Intraday precision study was performed and method was found to be precise. Recoveries obtained for the two drugs do not differ significantly from $100 \%$, which showed that there was no interference from 
TABLE 4: Result of recovery studies and interday precision.

\begin{tabular}{|c|c|c|c|c|c|}
\hline Day & $\begin{array}{l}\text { Label claim } \\
\text { (mg/tablet) }\end{array}$ & Amount added (\%) & $\begin{array}{l}\text { Total amount added } \\
(\mathrm{mg})\end{array}$ & $\begin{array}{c}\text { Concentration recovered } \\
(\text { mean } \pm \mathrm{SD})\end{array}$ & $\begin{array}{c}\text { \% recovery } \\
\text { estimated* } \\
(\text { mean } \pm \% \mathrm{SD})\end{array}$ \\
\hline \multirow{6}{*}{ Day 1} & \multirow{3}{*}{ ATR 10} & 80 & 8 & $8.02 \pm 0.34$ & $100.22 \pm 1.12$ \\
\hline & & 100 & 10 & $10.90 \pm 0.78$ & $98.10 \pm 0.98$ \\
\hline & & 120 & 12 & $12.23 \pm 0.89$ & $103.91 \pm 1.23$ \\
\hline & \multirow{3}{*}{ FEL 10} & 80 & 8 & $8.17 \pm 1.45$ & $101.70 \pm 1.18$ \\
\hline & & 100 & 10 & $10.71 \pm 1.78$ & $101.68 \pm 1.24$ \\
\hline & & 120 & 12 & $12.99 \pm 1.25$ & $99.93 \pm 0.98$ \\
\hline \multirow{6}{*}{ Day 2} & \multirow{3}{*}{ ATR 10} & 80 & 8 & $8.04 \pm 1.11$ & $101.11 \pm 1.25$ \\
\hline & & 100 & 10 & $10.08 \pm 1.45$ & $101.60 \pm 1.17$ \\
\hline & & 120 & 12 & $12.03 \pm 0.34$ & $100.64 \pm 1.11$ \\
\hline & \multirow{3}{*}{ FEL 10} & 80 & 8 & $8.17 \pm 1.71$ & $101.70 \pm 0.65$ \\
\hline & & 100 & 10 & $10.22 \pm 1.12$ & $97.76 \pm 0.34$ \\
\hline & & 120 & 12 & $12.54 \pm 0.34$ & $103.60 \pm 0.32$ \\
\hline
\end{tabular}

${ }^{*}$ Indicates $\pm \operatorname{SD}(n=3)$.

TABLE 5: Result of intraday precision.

\begin{tabular}{|c|c|c|c|c|c|}
\hline Day 1 & $\begin{array}{l}\text { Label claim } \\
\text { (mg/tablet) }\end{array}$ & Amount added (\%) & $\begin{array}{l}\text { Total amount } \\
\text { added (mg) }\end{array}$ & $\begin{array}{c}\text { Concentration } \\
\text { recovered* } \\
(\text { mean } \pm S D)\end{array}$ & $\begin{array}{c}\% \text { recovery } \\
\text { estimated } \\
(\text { mean } \pm \% \mathrm{SD})\end{array}$ \\
\hline \multirow{6}{*}{ Morning } & \multirow{3}{*}{ ATR 10} & 80 & 8 & $8.04 \pm 0.30$ & $100.22 \pm 1.12$ \\
\hline & & 100 & 10 & $10.10 \pm 0.34$ & $97.10 \pm 0.57$ \\
\hline & & 120 & 12 & $12.13 \pm 0.44$ & $102.79 \pm 1.52$ \\
\hline & \multirow{3}{*}{ FEL 10} & 80 & 8 & $8.27 \pm 1.47$ & $101.80 \pm 1.74$ \\
\hline & & 100 & 10 & $10.56 \pm 1.78$ & $101.32 \pm 1.04$ \\
\hline & & 120 & 12 & $12.90 \pm 1.28$ & $99.99 \pm 0.91$ \\
\hline \multirow{6}{*}{ Evening } & \multirow{3}{*}{ ATR 10} & 80 & 8 & $8.08 \pm 1.18$ & $101.64 \pm 1.17$ \\
\hline & & 100 & 10 & $10.04 \pm 1.55$ & $101.40 \pm 1.87$ \\
\hline & & 120 & 12 & $12.05 \pm 0.28$ & $101.55 \pm 1.13$ \\
\hline & \multirow{3}{*}{ FEL 10} & 80 & 8 & $8.11 \pm 1.54$ & $101.28 \pm 0.45$ \\
\hline & & 100 & 10 & $10.14 \pm 1.17$ & $99.68 \pm 0.56$ \\
\hline & & 120 & 12 & $12.99 \pm 1.98$ & $99.46 \pm 0.98$ \\
\hline
\end{tabular}

${ }^{*}$ Indicates $\pm \mathrm{SD}(n=3)$.

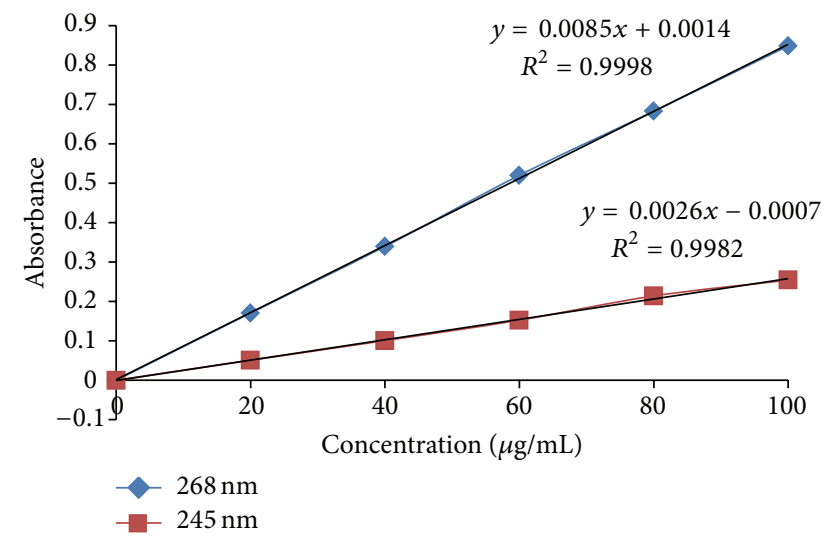

FIgURE 6: Calibration curve of ATR in ACN—water (70:30 v/v) — at 268 and $245 \mathrm{~nm}$.

common excipients used in the formulation indicating accuracy and reliability of the method (Table 5).

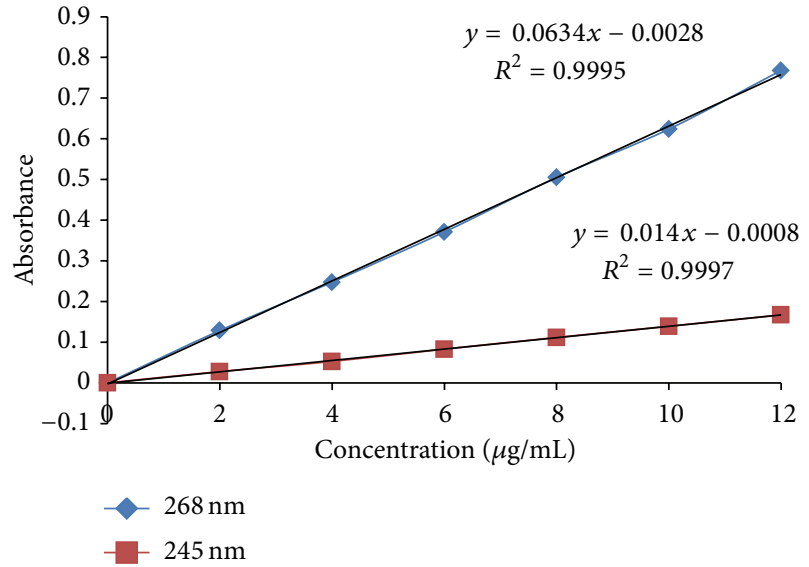

Figure 7: Calibration curve of FEL in ACN-water $(70: 30 \mathrm{v} / \mathrm{v})$ - at 268 and $245 \mathrm{~nm}$.

3.6. Ruggedness. Ruggedness of the method was tested using different chemical sources of acetonitrile and effects on 
TABLE 6: Ruggedness of the method.

\begin{tabular}{lccc}
\hline & $\begin{array}{l}\text { Label claim } \\
(\mathrm{mg} / \text { tablet })\end{array}$ & \multicolumn{2}{c}{$\begin{array}{c}\text { \% recovery estimated } \\
(\text { mean } \pm \text { \%SD) }\end{array}$} \\
\hline Source I & $100 / 10$ & ATR & FEL \\
Source II & $100 / 10$ & $102.74 \pm 0.35$ & $101.18 \pm 0.31$ \\
\hline
\end{tabular}

${ }^{*}$ Indicates $\pm \mathrm{SD}(n=3)$.

results were observed and shown in Table 6. From the result, it was found that method has ruggedness.

\section{Conclusion}

In present study, from the observation of the validation parameters, it can be concluded that the developed method is simple, accurate, reliable, and economical for the simultaneous quantitative estimation of atorvastatin calcium and felodipine from combined dosage form using UV spectrophotometric method.

\section{Conflict of Interests}

The authors declare that there is no conflict of interests regarding the publication of this paper.

\section{References}

[1] B. W. McCrindle, L. Ose, and A. D. Marais, "Efficacy and safety of atorvastatin in children and adolescents with familial hypercholesterolemia or severe hyperlipidemia: a multicenter, randomized, placebo-controlled trial," Journal of Pediatrics, vol. 143, no. 1, pp. 74-80, 2003.

[2] J. Villa and R. E. Pratley, "Ezetimibe/simvastatin or atorvastatin for the treatment of hypercholesterolemia in patients with the metabolic syndrome: the VYMET study," Current Diabetes Reports, vol. 10, no. 3, pp. 173-175, 2010.

[3] T. McCormack, P. Harvey, R. Gaunt, V. Allgar, R. Chipperfield, and P. Robinson, "Incremental cholesterol reduction with ezetimibe/simvastatin, atorvastatin and rosuvastatin in UK General Practice (IN-PRACTICE): randomised controlled trial of achievement of Joint British Societies (JBS-2) cholesterol targets," International Journal of Clinical Practice, vol. 64, no. 8, pp. 1052-1061, 2010.

[4] M. B. El-Hawary, M. T. khayall, and Z. Isaak, Hand Book of Pharmacology, The Scientific Book Center, S.O.P. Press, Cairo, Egypt, 1978.

[5] S. L. Thamake, S. D. Jadhav, and S. A. Pishawikar, "Development and validation of method for simultaneous estimation of atorvastatin calcium and ramipril from capsule dosage form by first order derivative spectroscopy," Asian Journal of Research in Chemistry, vol. 2, no. 1, pp. 52-53, 2009.

[6] R. Lakshmana, K. R. Rajeswari, and G. G. Sankar, "Spectrophotometric method for simultaneous estimation of atorvastatin and amlodipine in tablet dosage form," Research Journal of Pharmaceutical, Biological and Chemical Sciences, vol. 2, pp. 6669, 2010.
[7] M. Saravanamuthukumar, M. Palanivelu, K. Anandarajagopal, and D. Sridharan, "Simultaneous estimation and validation of atorvastatin calcium and ubidecarenone (Coenzyme Q10) in combined tablet dosage form by RP-HPLC method," International Journal of Pharmacy and Pharmaceutical Sciences, vol. 2, no. 2, pp. 36-38, 2010.

[8] L. Joseph, M. George, and B. V. R. Rao, "Simultaneous estimation of atorvastatin and ramipril by RP-HPLC and spectroscopy," Pakistan Journal of Pharmaceutical Sciences, vol. 21, no. 3, pp. 282-284, 2008.

[9] L. Nováková, D. Šatínský, and P. Solich, "HPLC methods for the determination of simvastatin and atorvastatin," Trends in Analytical Chemistry, vol. 27, no. 4, pp. 352-367, 2008.

[10] B. G. Chaudhari, N. M. Patel, and P. B. Shah, "Stability indicating RP-HPLC method for simultaneous determination of atorvastatin and amlodipine from their combination drug products," Chemical and Pharmaceutical Bulletin, vol. 55, no. 2, pp. 241246, 2007.

[11] A. Mohammadi, N. Rezanour, M. Ansari Dogaheh, F. Ghorbani Bidkorbeh, M. Hashem, and R. B. Walker, "A stability-indicating high performance liquid chromatographic (HPLC) assay for the simultaneous determination of atorvastatin and amlodipine in commercial tablets," Journal of Chromatography B: Analytical Technologies in the Biomedical and Life Sciences, vol. 846, no. 1-2, pp. 215-221, 2007.

[12] G. F. Patel, N. R. Vekariya, and R. B. Dholakiya, "Estimation of aspirin and atorvastatin calcium in combine dosage form using derivative spectrophotometric method," International Journal of Pharmaceutical Research, vol. 2, no. 1, pp. 62-66, 2010.

[13] N. R. Jadhav, R. S. Kambar, and S. J. Nadaf, "RP-HPLC method for simultaneous estimation of atorvastatin calcium and felodipine from tablet dosage form," Current Pharma Research, vol. 2, no. 4, pp. 637-642, 2012.

[14] A. J. López, V. Martínez, R. M. Alonso, and R. M. Jiménez, "High-performance liquid chromatography with amperometric detection applied to the screening of 1,4-dihydropyridines in human plasma," Journal of Chromatography, vol. 870, no. 1-2, pp. 105-114, 2010.

[15] A. B. Baranda, R. M. Jiménez, and R. M. Alonso, "Simultaneous determination of five 1,4-dihydropyridines in pharmaceutical formulations by high-performance liquid chromatographyamperometric detection," Journal of Chromatography A, vol. 1031, no. 1-2, pp. 275-280, 2004.

[16] J. Gottfries, J. Ahlbom, V. Harang et al., "Validation of an extended release tablet dissolution testing system using design and multivariate analysis," International Journal of Pharmaceutics, vol. 106, no. 2, pp. 141-148, 1994.

[17] B. Marciniec, E. Jaroszkiewicz, and M. Ogrodowczyk, "The effect of ionizing radiation on some derivatives of 1,4-dihydropyridine in the solid state," International Journal of Pharmaceutics, vol. 233, no. 1-2, pp. 207-215, 2002.

[18] K. Basavaiah, U. Chandrashekar, and H. C. Prameela, "Sensitive spectrophotometric determination of amlodipine and felodipine using iron(III) and ferricyanide," Farmaco II, vol. 58, no. 2, pp. 141-148, 2003.

[19] K. Rajesh, R. Rajalakshmi, S. Vijayaraj, and T. Sreelakshmi, "Simultaneous estimation of atorvastatin calcium and felodipine by UV-spectrophotometric method in formulation," Asian Journal of Research in Chemistry, vol. 4, no. 8, pp. 1202-1205, 2011. 

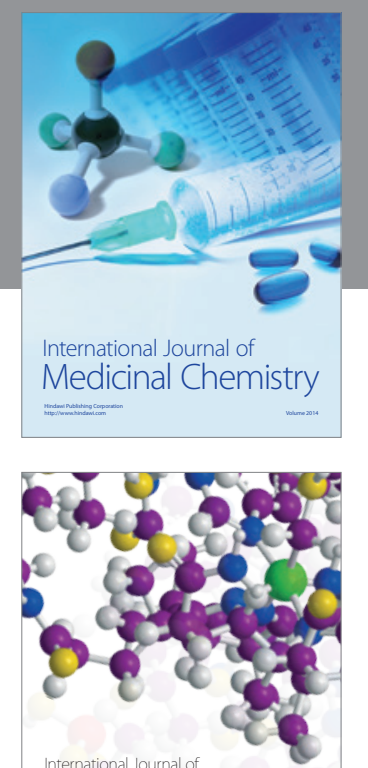

\section{Carbohydrate} Chemistry

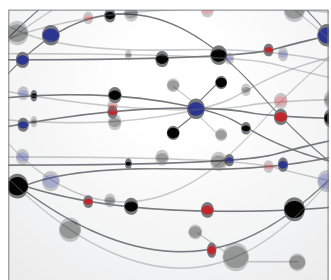

The Scientific World Journal
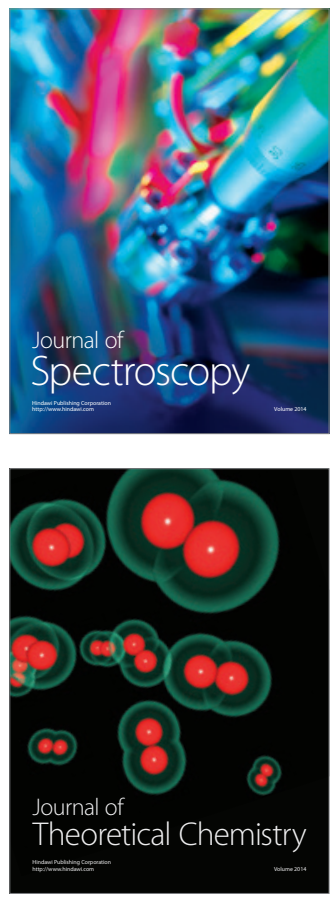
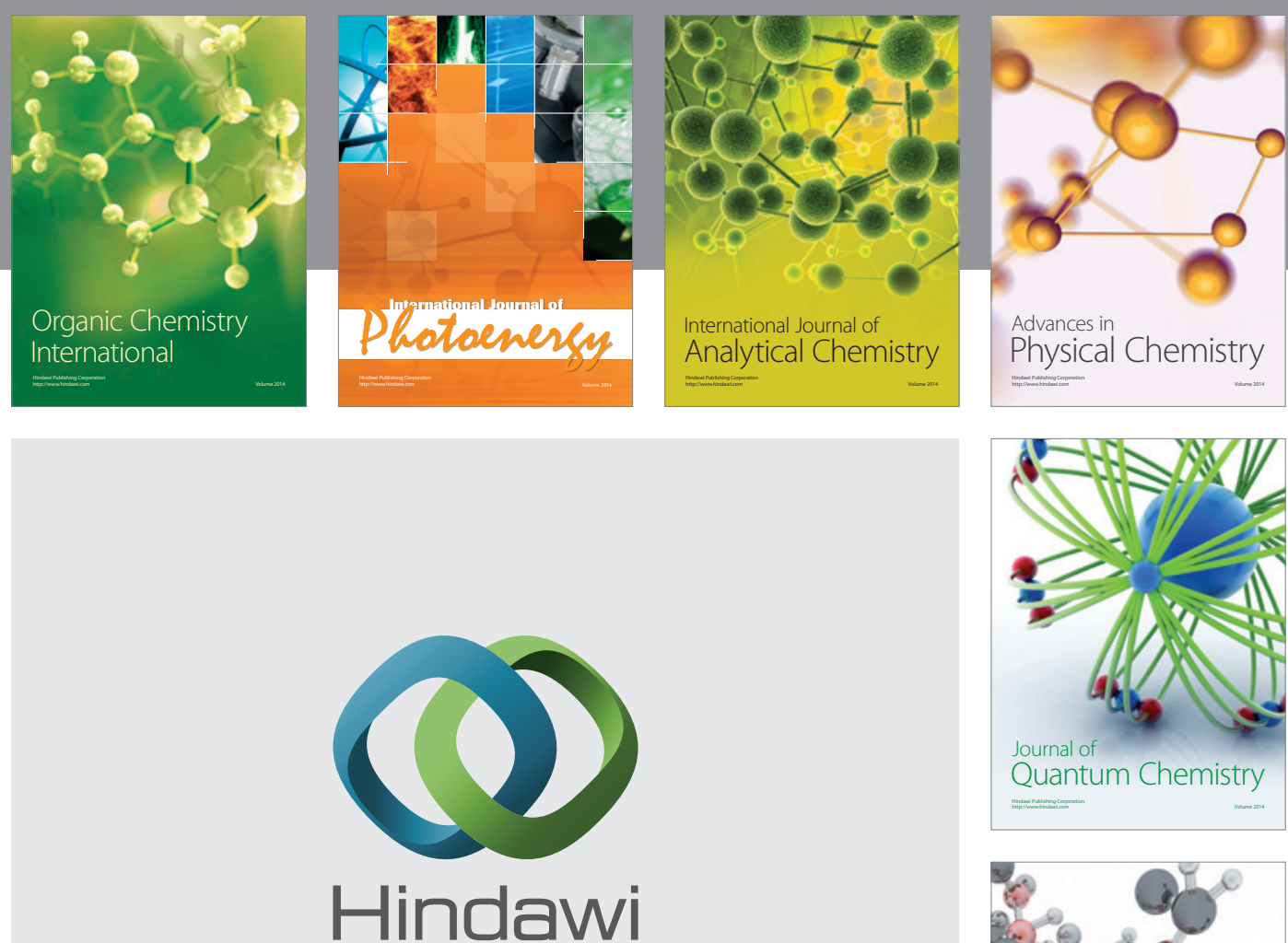

Submit your manuscripts at

http://www.hindawi.com

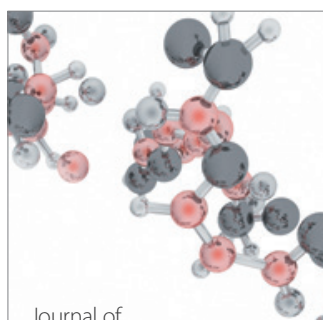

Analytical Methods

in Chemistry

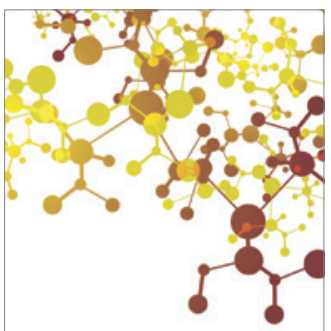

Journal of

Applied Chemistry

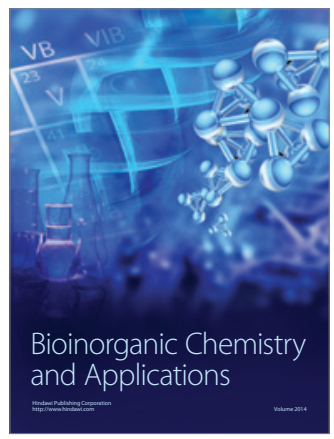

Inorganic Chemistry
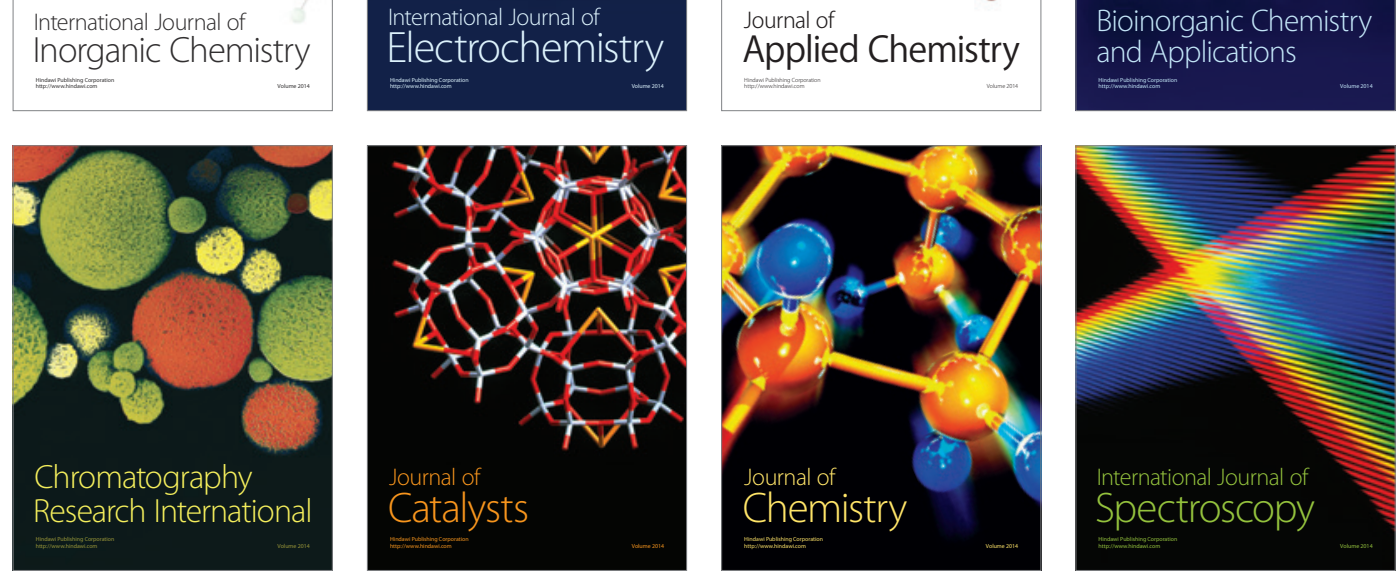